(昭和 35 年 7 月 15 日受理)

浸水処理による撚り止め举動の研究

岐鼻大学工学部 古里孝吉

\title{
STUDIES ON THE BEHAVIOR OF TWIST SETTING TREATMENTS IN WATER
}

By Kokichi Furusato

(Faculty of Engineering, Gifu University, Naka-Machi, Gifu Prefecture, Japan)

Resilience is suppressed as the twist setting treatments are given to yarn for finishing. But

$S$ (twist set percentage of yarn) is not a constant.

The results on the yarn given by varied bath temperatures are as follows:

(1) At $10^{\circ} \mathrm{C} S$ of worsted yarn decreases from $95 \%$ to $85 \%$ and $S$ of woollen yarn from $91 \%$ to $43 \%$.

(2) This declining tendency gaes on up to $40^{\circ} \mathrm{C}$.

(3) As the setting property of fibers in woollen yarn bigins to appear at $60^{\circ} \mathrm{C}$, value $S$ rises again.

(Received July 15, 1960)

\section{1. 緒言}

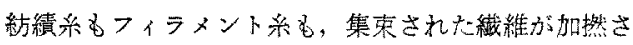
れ据られて变形し，その系としての形態や﨡能が生れて Wる。

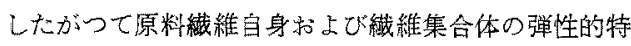
性々して，その系には握り方向に対する反発性があらわ

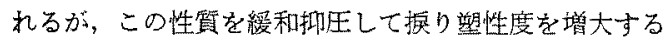
目的で行なかれる糸の然りどめ処理によつて，反発力は ある一定值をとるに至る。

しかし処理以前上りは安定した状態にあるとはいえ， 以後全くこの一定值にとどまる場合のみではなく，原料

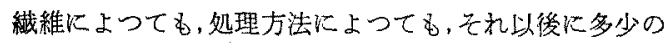
変化はみられ，ことに撚り止め処理以後に条の沶かれる 条件 (温度, 湿度1), 張力，横王力, 浴中処理など) に よつては，影響を受け，例えば糸が製織售備，製織，仕

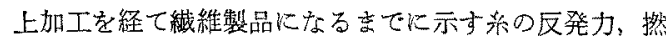
り止め率の推移にも與味的る経過3がみられる。

本研究ではその条件の一つとして瀻維整品が生産され るなでに䒺がしばしば受ける浴中処理での然り止めの举 動索知る目的で，著者が先に試作した撚り止㛙测定 機4を用い，これに浴中での糸の反発力を測定できる装 置を試作併用し，羊毛䒺を圾料として案驗を行なつたの でここに報告する。

\section{2. 実験方法}

\section{1) 試州}

精紀後 2 カ月経過し，一定然り止め率に䢰している試

\begin{tabular}{|c|c|c|c|c|c|c|}
\hline $\begin{array}{l}\text { 系の } \\
\text { 種類 }\end{array}$ & 番手 & 原料調合率(\%) & 賀鼻 & {$\left[\begin{array}{l}\text { 平均穖維 } \\
\text { (in) }\end{array}\right.$} & 撚数 $/ \mathrm{m}$ & 符号 \\
\hline 紡 & 14 & $\mid \begin{array}{ll}\text { 新毛 } & 60 \\
\text { フレンキノイル10 } \\
\text { 由无ス反毛 } 30\end{array}$ & 64 & 1.5 & 518 & $A$ \\
\hline 毛 & 14 & $\begin{array}{l}\text { アミ毛反毛 } 60 \\
\text { ナイロン(3D) } 20 \\
\text { ナイロン匢毛20 }\end{array}$ & & 2.0 & 495 & B \\
\hline 苏 & 16 & $\begin{array}{lr}\text { ナイ } & \text { (3D) } 20 \\
\text { フイ } & 20 \\
\text { ファイン } & 260\end{array}$ & & 2.0 & 510 & $\mathrm{C}$ \\
\hline z & $2 / 36$ & 欧 100 & 67 & 2.5 & $\begin{array}{lll}\text { 上撚 } & 500 \\
\text { 下然 } & 5050 & 550 \\
\end{array}$ & $D$ \\
\hline $\begin{array}{l}\text { 毛 } \\
\text { 系 }\end{array}$ & $2 / 48$ & $\mid \begin{array}{lr}\text { イングランド50 } \\
\text { ペルギフン } 50\end{array}$ & $\begin{array}{l}64 \\
65\end{array}$ & 2.5 & $\begin{array}{|ll|}\text { 上撚り } & 590 \\
\text { 下撚り } & 650\end{array}$ & $\mathrm{E}$ \\
\hline
\end{tabular}

料を用いた。

2) 測定法

試作して测定に使用した装置を示す。

試料を上部フック（A）と下部クリップ (B) との間 に取付ける間は，ポりエテレン製容器 (C) は図のよう

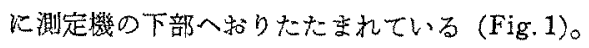

試料を取付けた後は容器は引延され，この容器上部周 辺のフックは3本の支柱（D）の上端の上的金（E）K 引かけられる(Fig.2)。

細い棒（F）は下端にフック（A）を，上端に他のフ ックを持ら、これにひつかかる15dのサイロンで測定機 の本体のクリッブ（G）に吊されている。换りもーメン 


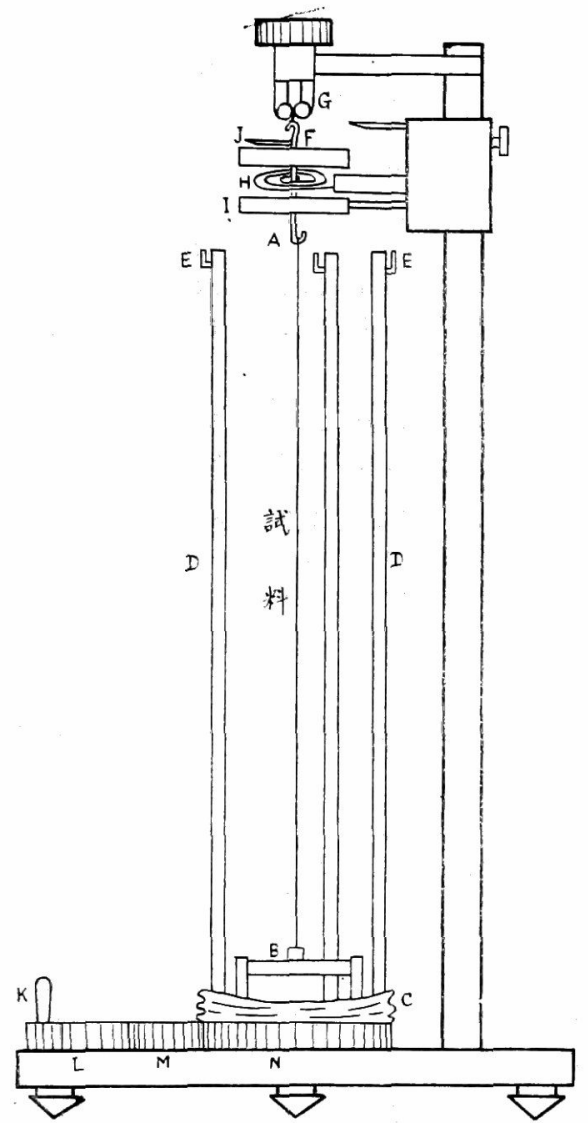

Fig. 1. Apparatus for measuremet of twist set. トを測定するために準備された燐青銅製渦巻バネ（H） (幅 $35 \times 10^{-3} \mathrm{~cm}$, 厚さ $35 \times 10^{-4} \mathrm{~cm}$, 長さ $25 \mathrm{~cm}$, 縦弾 性係数 $1.4 \times 10^{5} \mathrm{~g} / \mathrm{cm}^{2}$, 回転力 $7.5 \mathrm{mg}-\mathrm{cm} / 90^{\circ}$ ) は, 外 側の末端を測定機の本体に，内䝨の末端は（F）汇取付 けられている。

この（F）についている十字棒は, 測定時以外すなわ ら試料をこの装置に取付けるとき, 測定が終わつて試料 を除く時には上下可動のリング ( I ) が上り，その上に 垂つて渦巻バネを主体とする測定主要部は静止するよう に考案されている。

試料を取付计た後（I）を下け゚ると，測定部は吊り下 げられた状態で浮さ，一方試料のるつ抳りモーメントに よつて（F）は，これに取付けられている渦巻バネの回 転力と平衡状態を保つまで一定方向へ回転して静止す る。この回転角度は，（F）から出ている細い指針（J） が (H) の上面のダイヤル面上の目盛を指すので, これ を読み取る。上記のごとく，バネの回転力は既知である から，この指針の示方角度から試料の捠りモーメントは

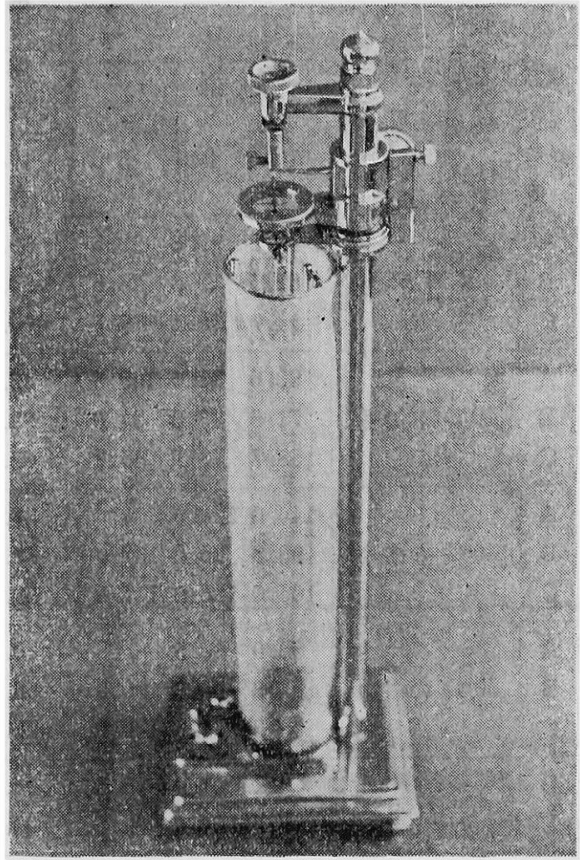

Fig. 2

換算できる。

上記の如く試料を取付けポリエチレン容器を引延ばし て試料の外周をつつみ, 一方電気恒温槽で必要な一定温 度に加熱された水は, 短いサイフォンによつてポリェチ レン容器へ注入され, 他のサイフォンで恒温槽へオーバ ーフローをかえし, 試料はたえず一定温度の浴中に浸せ きされる。

試料は一定時間浸せきされた後, 上部測定部を作動さ せてその系に固有なモーメントを求める。次にハンドル (K)をまわすと（L）（M）（N）の歯車が回転し，試料 の下端を支持するクリップ（B）が一定方向へ回転する ので解撚作用が与党られ，モーメントの減少を指針の角 度の減少から読みとる。この操作をくり返し，ついには 指針が目盛板の0を示し, 采のモーメンドが0に至る が，測定当初からこの時までに放出したモーメントの積 分によつてレジリエンスを算出する。

この時, 試料に存在した浮遊撚の数は, モーメント0 に至る亡でのハンドルの回転数で与充られるから, 次式 によつて撚り止め率は求められる。

撚り止め率 $(S)=\frac{\text { (与えた撚数 })-(\text { 浮遊撚数 })}{\text { (与穴た撚数 })} \times 100(\%)$

なお測定時, 糸に与える張力を変えるためには, クリ ップ（B）の下に吊りさげる拈もりを取りかえる。

\section{3. 測 定結 果}


第 2 斐

\begin{tabular}{|c|c|c|c|c|c|c|c|c|c|c|c|c|c|c|}
\hline \multicolumn{3}{|c|}{ 試料上測定条件 } & \multicolumn{3}{|c|}{$\begin{array}{c}\text { 浩 摖 } \\
(30 \mathrm{~cm} \text { 数 }\end{array}$} & \multicolumn{3}{|c|}{ 撚 引 $\frac{\text { 步 }}{(\%)}$} & \multicolumn{3}{|c|}{$\begin{array}{c}\text { 系の当初の正- } \\
(\mathrm{mg}-\mathrm{cm})\end{array}$} & \multicolumn{3}{|c|}{ 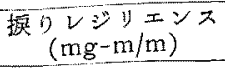 } \\
\hline & 符号 & $\begin{array}{c}\text { 测定眭の系 } \\
\text { の㖘力 }(\mathrm{g}) \\
\text { 測定の状態 }\end{array}$ & 1.4 & 3.0 & 5.0 & 1.4 & 3.0 & 5.0 & 1. 4 & 3. 0 & 5.0 & 1.4 & 3.0 & 5.0 \\
\hline \multirow{4}{*}{ 紡 } & A & \multirow{3}{*}{ 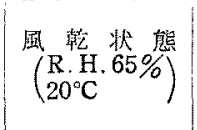 } & 14.2 & 19.5 & 23.5 & 90.9 & 87.6 & 85.0 & 18.2 & 18.7 & 23.7 & 22.0 & 29.7 & 38.0 \\
\hline & B & & 22.5 & 27.6 & 28.6 & 85.0 & 81.6 & 80.9 & 20.5 & 21.1 & 23.1 & 34.2 & 50.3 & 53.0 \\
\hline & C & & 14.0 & 19.1 & 19.7 & 90.9 & 87.6 & 87.3 & 10.7 & 13.7 & 17.2 & 13.3 & 23.4 & 28.6 \\
\hline & A & \multirow{3}{*}{$10^{\circ} \mathrm{C}$ の水蛇 } & 90.0 & 91.0 & 103.4 & 42.6 & 42.0 & 34.1 & 17.2 & 16.2 & 20.0 & 85.5 & 85.2 & 119 \\
\hline \multirow{2}{*}{ 毛 } & B & & 71.6 & 73.0 & 81.0 & 52.2 & 51.3 & 46.0 & 12.5 & 14.0 & 17.8 & 50.3 & 61.4 & 91.4 \\
\hline & $\mathrm{C}$ & & 58.7 & 73.7 & 86.2 & 62.0 & 52.3 & 44.2 & 9.8 & 12.2 & 14.7 & 39.4 & 57.9 & 74.7 \\
\hline \multirow{6}{*}{ 系 } & A & \multirow{3}{*}{$40^{\circ} \mathrm{C}$ の浴中 } & 114.0 & 122.5 & & 27.3 & 21.9 & & 11.1 & 13.3 & 12.9 & 83.8 & 97.7 & \\
\hline & B & & 93.3 & 95.0 & 107.4 & 37.8 & 36.6 & 27.7 & 8.9 & 13.3 & 13.2 & 54.4 & 84.1 & 93.6 \\
\hline & $\mathrm{C}$ & & 105.0 & 105.0 & 117.5 & 32.1 & 32.1 & 24.0 & 8.7 & 11.0 & 15.1 & 61.1 & 74,0 & 101.6 \\
\hline & A & \multirow{3}{*}{$60^{\circ} \mathrm{C}$ の浴中 } & 80.0 & 82.5 & & 49.0 & 47.4 & & 7.8 & 9.0 & 10.9 & 43.3 & 59.7 & \\
\hline & B & & 67.3 & 96.2 & 100.0 & 55.0 & 35.8 & 33.3 & 8.5 & 11.7 & 13.4 & 44.0 & 76.8 & 95.6 \\
\hline & $\mathrm{C}$ & & 68.3 & 85.0 & 103.3 & 55.8 & 45.0 & 33.2 & 8.5 & 9.2 & 13.2 & 38.0 & 56.2 & 90.7 \\
\hline \multirow{4}{*}{ 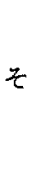 } & D & \multirow{2}{*}{ 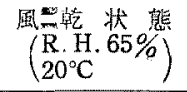 } & 8.1 & 11.4 & 11.3 & 94.6 & 92.4 & 92.4 & 5.7 & 8.4 & 8.4 & 5.1 & 10.1 & 9.4 \\
\hline & $\mathrm{E}$ & & 7.5 & 10.0 & 12.2 & 95.8 & 94.4 & 93.1 & 4.3 & 6.0 & 9.3 & 3.5 & 6.3 & 11.9 \\
\hline & D & \multirow{2}{*}{$10^{\circ} \mathrm{C}$ の水中 } & 21.6 & 27.7 & 31.0 & 85.6 & 81.5 & 79.3 & 5.2 & 7.1 & 9.6 & 9.8 & 17.5 & 28.9 \\
\hline & $\mathrm{E}$ & & 16.8 & 28.8 & 34.5 & 90.5 & 83.7 & 80.5 & 3.6 & 6.1 & 8.0 & 5.6 & 16.1 & 24.6 \\
\hline \multirow{2}{*}{ 毛 } & D & \multirow{2}{*}{$40^{\circ} \mathrm{C}$ の浴中 } & 28.7 & 41.2 & 50.6 & 80.9 & 72.5 & 66.3 & 3.4 & 5.7 & 9.1 & 8.9 & 22.7 & 43.3 \\
\hline & $\mathrm{E}$ & & 27.2 & 43.7 & 59.0 & 84.6 & 75.3 & 66.7 & 2.8 & 4. 9 & 7.7 & 8.3 & 19.3 & 41.2 \\
\hline \multirow[t]{2}{*}{ 木 } & D & \multirow{2}{*}{$60^{\circ} \mathrm{C}$ の浴中 } & 26.6 & 41.0 & 50 & 82.3 & 72.7 & 66.3 & 3.7 & 7.5 & 8.7 & 9.6 & 29.8 & 42.4 \\
\hline & $\mathrm{E}$ & & 31.0 & 51.2 & 58.0 & 82.5 & 71.1 & 67.2 & 3.7 & 5.9 & 6.7 & 9.9 & 36.6 & 36.6 \\
\hline
\end{tabular}

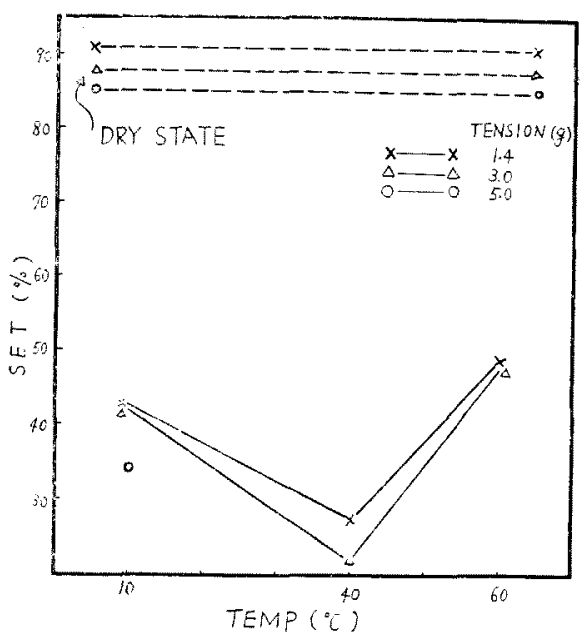

Fig. 3. (a)

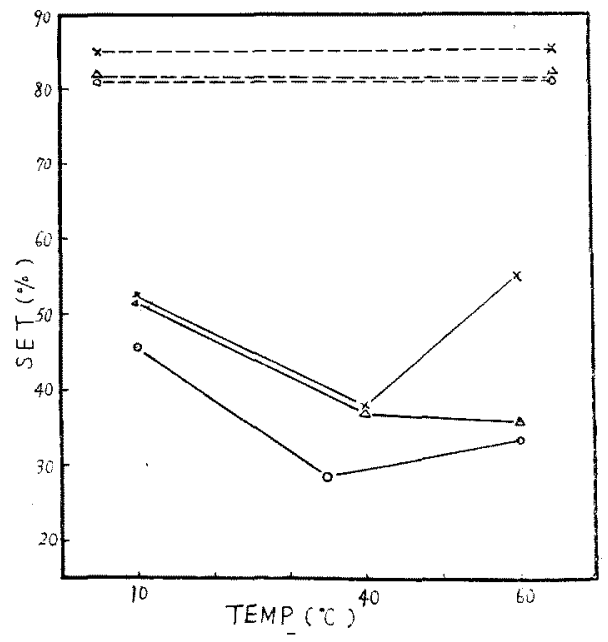

Fig. 3. (b) 


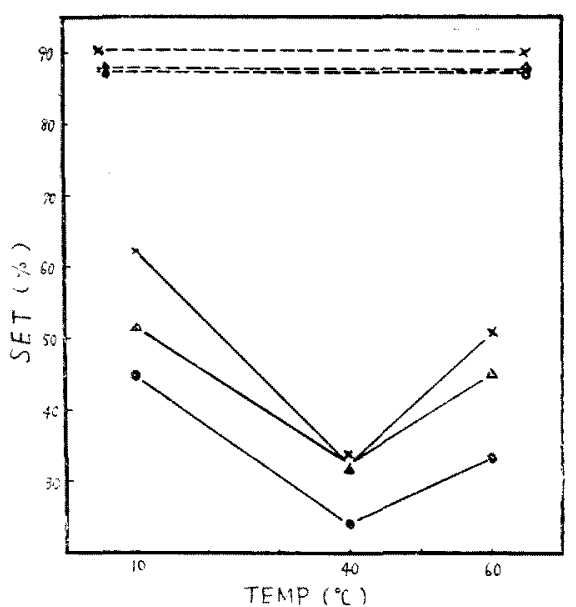

Fig. 3. (c)

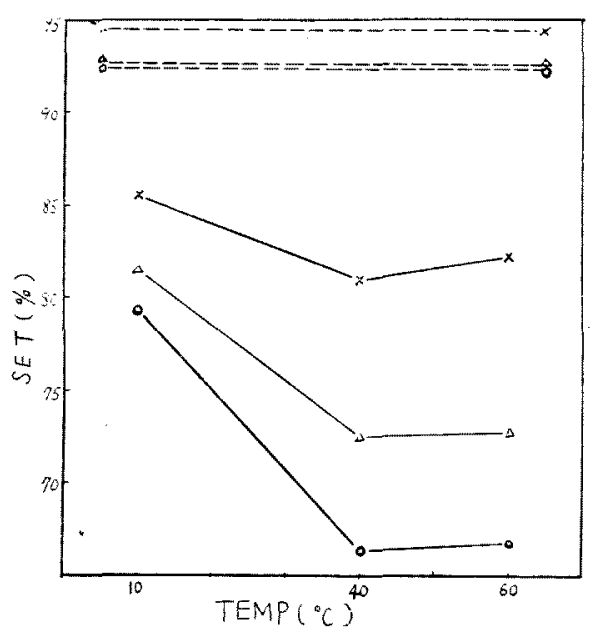

Fig. 3. (d)

\section{4. 考察とむすひ}

試料には紡績後 2 カ月経過したそ毛系小よび紡毛采を 用いたので，応力緩和は充分で，撚り止め率はそ毛系で 92 96\%，紡毛系で 80 91\% に出よんでおり，撚り止 めはほとんどー定状態に達している。

しかし水中への浸せき処理によつて，瀻維に与えられ ている歪の緩和収樎と膨潤とが起こり，集束され強制変 形されて一旦は安定状態を保つていた羊毛紻維もその平 衡が破られ，水中での上り安定な状態への活動が起こ $り$ ，加然時とは这方向の回転反発力が発生し解撚現象を 呈して撚り止め率の低下となる。

（1）撚り止め率への影響は $10^{\circ} \mathrm{C}$ の水中への浸せき

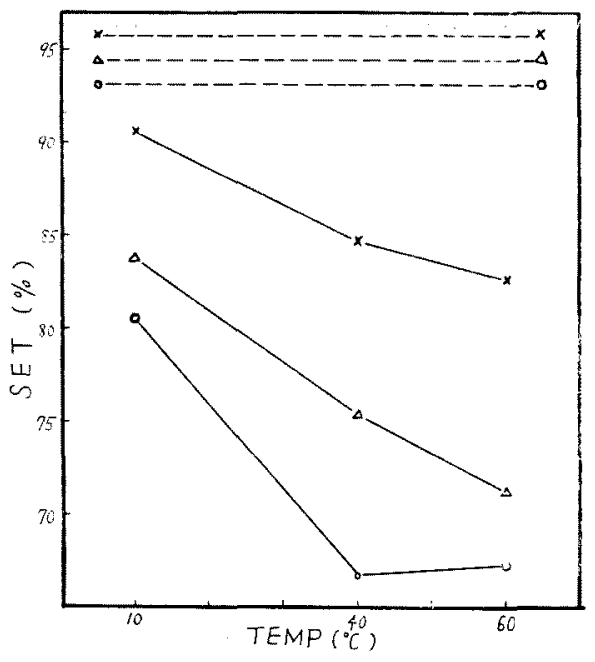

Fig. 3. (e)

Fig. 3. (a) (e) Relation between twist setting and various temperatures treated.

によつても明らかに示され，采体内では比較的自由度を もつ繊維から成る紡毛杀では，1/2 にも減少する場合も みられるが，一般的には 34〜62\% となり，䋊維平行度 が良好で系体内では絨維は主しろ强制整形されていると みられると毛系でも，撚り此率は79〜90\% となり， 反発力の增加傾向が文々められる。

水温を㟧げて $40^{\circ} \mathrm{C}$ の浴中では，この低下傾向は更に 続き，紡毛糸では風翰時の $1 / 4$ 亿相当する例もみられて 21 37\% に達し，そ毛系では紡毛系ほど影著てはない が 66〜84\% になる。

更に界温して $60^{\circ} \mathrm{C}$ の浴中では，そ毛采は $40^{\circ} \mathrm{C}$ の場 合と特に変わつた現象はみられず,一応安定な状態に達 していると認められるが，紡毛杀では一旦反発力の復元 を起こしていた紻維群にもこの熱水浸せきによつて熱固 定現象が起こり，低下していた撚り止め率は再び向上し て 33〜56\%になる。

このよ5に一旦安定化したとみられる撚り止めも，浸 水や薬剤処理によりその安定が破燷される現象は綿系合 織系などにも認められら，系の応用的性能としてみてる 興味が持たれるところである。

（2）測定時系に与兄られる張力の影響をみると，米 末端汇回転力として現われる反発力に対して張力は綡軸 方向へ作用するので, 兼の一端を自由にした時捊遊撚々 して外部へ放出される采の末端の回転は一定数を示して 止まるが，張力の大きい時には糸を構成する緎維の構造 上の安定が更に破壊され，総合的には反発力の增大（風

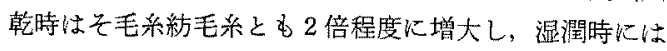




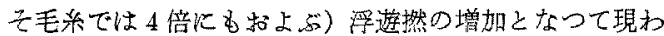
れ然り上め染の減少となる。

この傾向は浴温にも影響され，水温の上年とともに顕 著であり，60\% 浴中では張力 $5 \mathrm{~g}$ ては $1.4 \mathrm{~g}$ の测定值に

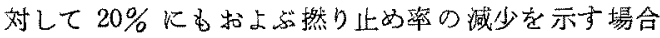

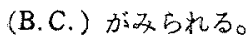

付記：本研究に対し種々助言を賜わつた信大柳沢教 授，小林助教授，実験遂行に協力された小山定氏，試料 を提供された長野紡績 $\mathrm{KK}$ ，扣よび長野紡毛 $\mathrm{KK}$ 汇感
謝いたします。

文 献

1) J.M.Gregory ; J. Text. Inst., 47, T541 (1956)

2) 中島杂男; 繊機学誌, 8，814 (1955)

3）著者；綿研・研究報告・撚りのセッティング方法 の研究 (II) (1961)

4) 著者; 䄸研・研究翢告 No.21 撚りのセッティン グ方法の研究 (I) (1957)

5)蓄者；3）と同じ 